\title{
MONIAMMATILLINEN SUURSIMULAATIO OPISKELIJOIDEN OPPIMISEN NÄKÖKULMASTA
}

Taru Kekoni: YTT, yliopistonlehtori, Itä-Suomen yliopisto

Kaarina Mönkkönen: YTT, yliopistonlebtori, dosentti, Itä-Suomen yliopisto

Marja Silén-Lipponen: FT, yliopettaja, Savonia-ammattikorkeakoulu

Miia Tiihonen: FaT, yliopistotutkija, dosentti, Itä-Suomen yliopisto

Terhi Saaranen: professori (ma.), Itä-Suomen yliopisto

taru.kekoni@ueffi; kaarina.monk.konen@uef.fi;

marja.silen-lipponen@savonia.fi; miia.tiihonen@uef.fi; terbi.saaranen@uef.fi

Janus vol. 29 (4) 2021, 366-385

Tiivistelmä

Artikkelissa tarkastellaan uuden simulaatio-oppimisen menetelmän -suursimulaation- merkitystä sosiaalityön ja sosiaalipsykologian opiskelijoiden oppimisen näkökulmasta. Etsimme vastauksia seuraaviin tutkimuskysymyksiin: mitä opiskelijat oppivat moniammatillisesta työskentelystä suursimulaatiota seuratessaan ja sitä jälkeenpäin oppimistehtävissä reflektoidessaan sekä millaisia havaintoja opiskelijat tekivät suursimulaatioon osallistuttuaan simulaatio-oppimisesta. Suursimulaatiolla tarkoitetaan draamaperustaisesti, näyttelijöiden ja eri alojen ammattilaisten avustuksella toteutettua simulaatioharjoitusta, jota voi olla seuraamassa satoja eri alojen opiskelijoita ja ammattilaisia yhtä aikaa. Artikkelin aineistona olivat sosiaalityön ja sosiaalipsykologian opiskelijoiden oppimisreflektiot kahdesta moniammatillisesta suursimulaatiosta, ja ne analysoitiin aineistolähtöisen sisällönanalyysin menetelmällä. Tutkimuksen tuloksena esitetään, että suursimulaatio on hyvä moniammatillisuuden opetus- ja oppimismenetelmä, sillä havainnoinnin keinoin voi oppia paljon moniammatillisuuden käytännöistä ja merkityksistä. Oppimiskokemukset kiinnittyvät sisällöllisesti moniammatillisuuden vaatimuksien ja sen tuottamien hyötyjen havaitsemiseen ja oppimiskokemuksen reflektoinnin näkökulmasta suursimulaation pedagogisten vahvuuksien pohtimiseen.

\section{JOHDANTO}

Sosiaalityön ammattikäytännöissä moniammatillinen yhteistyö on ollut keskustelussa jo muutaman vuosikymmenen ajan, ja sen rooli on koko ajan vahvistunut. Monitieteisen opetuksen kehittämisen lähtökohdat ankkuroituvat meneillään oleviin laajempiin työelämän muutoksiin, mutta ennen kaikkea sosiaali- ja terveyspalveluiden integraatioon liittyvään kehitykseen. Monissa kehittämisohjelmissa on viime aikoina asetettu tavoitteeksi eri ammattialojen toimijoiden tiiviimpi yhteistyö sen sijaan, että ammattilaiset toimivat totuttuun tapaan omissa “siiloissaan” (esim. OKM 2019). Uu- simmissa simulaatiopedagogiikan tutkimuksissa on tuotu esille näkökulma, että monitieteinen työskentely ja siihen oppiminen on tärkeää aloittaa jo opiskeluaikana, ja mitä aiemmin, sen parempi (Tervaskanto-Mäentausta 2018). Myös yliopistot korostavat strategioissaan monitieteisyyden merkitystä niin tutkimuksessa kuin koulutuksessakin. Moniammatillista koulutusta (interprofessional education, IPE) tarvitaan eri ammattilaisten tuottaman asiantuntijatiedon yhdistämiseksi ja koordinoidun tuen saamiseksi asiakkaalle. Tämän vuoksi sosiaalityönkin opetuksessa monitieteisten opintojen määrä on lisääntynyt. Tutkimustulosten mukaan moniammatillinen koulutus parantaa 
ammattien välistä yhteistyötä ja madaltaa ammattien välisiä ennakkokäsityksiä (esim. Shrader ym. 2013; Bayne-Smith ym. 2014).

Moniammatillisella tiimityöllä on tärkeä merkitys erityisesti vaativissa asiakastilanteissa kuten kriisi- tai väkivaltatilanteissa. Näissä tilanteissa ammattilaisten on tärkeä osata työskennellä yhdessä tehokkaasti ja inhimillisesti asiakkaita kunnioittaen. Akuuteissa tilanteissa ongelmat on ratkaistava nopeasti, eikä yhteiselle harkinnalle ja eri ammattilaisten tekemien ratkaisujen pohdinnalle jää aikaa. Jälkeenpäin ammattilaiset saattavat kuitenkin arvioida omia tai toisten ammattilaisten tekemiä ratkaisuja tuoden esille esimerkiksi niihin liittyviä eettisiä ristiriitoja (Banks \& Williams 2008; Mönkkönen ym. 2021). Kun opiskelijat ja ammattilaiset saavat mahdollisuuden reflektoida tilanteita yhdessä opintojen tai täydennyskoulutuksen aikana, heille avautuu aikaisempaa laajempi käsitys toisten ammattilaisten toiminnasta.

Tässä tutkimuksessa olemme kiinnostuneita siitä, millaisena kehittämämme simulaatio-oppimisen menetelmä -suursimulaatio- näyttäytyy sosiaalityön ja sosiaalipsykologian opiskelijoiden moniammatillisen oppimisen näkökulmasta. Suursimulaatiolla tarkoitetaan draamaperustaisesti, näyttelijöiden ja eri alojen ammattilaisten avustuksella toteutettua simulaatioharjoitusta, jota seuraamassa on suuri joukko opiskelijoita ja tässä tapauksessa myös eri alojen ammattilaisia. Oppijat (eli tilaisuuden yleisö) eivät itse osallistu simulaatioharjoitukseen, vaan seuraavat sitä havainnoijina. Sen sijaan he osallistuvat simulaation jälkeen käytyyn oppimis- keskusteluun, joka on keskeinen osa simulaatio-oppimista. Kysymme tutkimuksessamme, mitä opiskelijat oppivat moniammatillisesta työskentelystä suursimulaatiota seuratessaan ja sitä jälkeenpäin oppimistehtävissä reflektoidessaan. Lisäksi olemme kiinnostuneita siitä, millaisia havaintoja opiskelijat tekivät suursimulaatioon osallistuttuaan simulaatio-oppimisesta. Tutkimusaineistona käytettiin suursimulaatioon havainnoijina osallistuneiden sosiaalityön ja sosiaalipsykologian opiskelijoiden oppimisreflektioita.

Tämän artikkelin kirjoittajat ovat eri tieteenalojen ja oppilaitosten opettajia, jotka suunnittelivat ja toteuttivat suursimulaation. Käymme artikkelissa ensin läpi simulaatio-oppimisen pedagogisia lähtökohtia ja asemoimme tutkimuksemme osaksi moniammatillisen simulaatio-oppimisen teoreettista keskustelua. Tämän jälkeen kuvaamme lyhyesti suursimulaation toteutustavat ja kahden jo toteutuneen simulaation kulun. Seuraavaksi esittelemme tutkimuksemme aineiston, kysymyksenasettelun ja menetelmät, jonka jälkeen raportoimme tutkimuksen tulokset. Lopuksi pohdimme tuloksiamme suhteessa yleiseen keskusteluun moniammatillisesta opetuksesta ja simulaatio-opetuksesta. Kohdennamme tarkastelun eri alojen yhteiseen oppimiseen, emmekä tässä artikkelissa kuvaa tarkemmin minkään alan erityiskysymyksï.

\section{SiMULAATIO-OPPIMISEN PEDAGOGISET LÄHTÖKOHDAT}

Simulaatio-oppimisen pedagogiset lähtökohdat ovat vahvasti konstruktivistisessa oppimiskäsityksessä. Konstruktivistiseen oppimiseen, kuten myös 
simulaatio-oppimiseen, kuuluu sosiaalinen ja yhteisöllinen ulottuvuus, jossa opitaan monipuolisesti yhdessä asioita tarkastellen. Myös oppimisen tilannesidonnaisuus on keskeinen periaate simulaatio-oppimisessa, jossa muistin ja oppimisen tilannesidonnaisuutta pyritään hyödyntämään rakentamalla simulaatioharjoitus mahdollisimman "autenttiseksi". (Eteläpelto ym. 2013.) Aidonkaltaisen simulaatioympäristön avulla simulaatio-oppimisessa tavoitellaan tilannetta, jossa oppija "unohtaa" olevansa simulaatioharjoituksessa ja ikään kuin kuvittelee olevansa aidossa tilanteessa, jota simulaatioharjoitus jäljittelee. Simulaatio-oppiminen voidaan yhdistää myös kokemuksellisen oppimisen malliin (Kolb 1984).

Konstruktivistisessa oppimisessa korostetaan tiedon ja toiminnan kiinteää yhteyttä. Käytännössä se tarkoittaa opiskelijoiden aktiivista osallistamista oppimiseen, jotta heidän luova ajattelunsa, tilannetietoisuutensa ja ongelmanratkaisutaitonsa kehittyvät (Bambini 2016; Bland \& Tobbell 2016). Siksi erityisen tärkeää on vaalia oppimiselle suotuisaa ja turvallista ilmapiiriä, jotta oppijat rohkenevat oppimaan ja heittäytymään tilanteisiin pelkäämättä virheitä tai osaamattomuutta (Reime ym. 2017). Edellä kuvatut periaatteet toteutuvat hyvin pienryhmäsimulaatioissa. (Eteläpelto ym. 2013). Tässä artikkelissa käsiteltävä suursimulaatiooppiminen perustuu osin samoihin pedagogisiin lähtökohtiin, mutta kokemuksellinen ja sosiokonstruktivistinen oppiminen saavat suursimulaatio-oppimisessa osin erilaisia painotuksia kuin pienryhmäopetukseen perustuvassa simulaatio-oppimisessa. Suursimulaatiossa opiskelijat eivät saa omakohtais- ta kokemusta simulaatioon toimijoina osallistumisesta (Bambini 2016; Bland \& Tobbell 2016), mutta saavat havainnoijina kokemuksia, jotka voivat olla yhtä vahvoja kuin itse toimiessa saadut kokemukset (Stegmann ym. 2012). Kyse on kokemuksellisesta ja sosiokonstruktivistisesta oppimistilanteesta, jossa opiskelijat havainnoivat simulaatiota osana suurta oppijajoukkoa ja eläytyvät siinä tapahtuviin tilanteisiin. Opiskelijat osallistuvat myös yhteiseen oppimiskeskusteluun, jossa tuodaan esille, kuten pienryhmäsimulaatioissakin, sekä toimijoiden että havainnoijien näkökulmia ja kokemuksia simulaatioharjoituksesta (Lavoie ym. 2015).

Simulaatio-oppiminen sisältää myös integratiivisen oppimisen periaatteita, koska siinä yhdistetään monipuolisesti erilaisia oppimismenetelmiä ja pedagogisia toimintatapoja (esim. Tynjälä 2007; Tynjälä ym. 2016). Kuten simulaatiooppimisessa, myös integratiivisessa pedagogiikassa oppijan sosiaalinen, kognitiivinen ja tunteiden taso ovat vahvasti mukana oppimisessa ja siksi oppiminen on kokonaisvaltaista. Yhteistä integratiiviselle pedagogiikalle ja simulaatiooppimiselle on myös se, että oppimisen tärkeänä osana pidetään reflektointia. Simulaatio-oppimisessa oppimiskeskustelu edustaa oppimisen reflektiivistä vaihetta, jossa sekä myönteisï että kielteisiä kokemuksia tarkastellaan oppimisen tavoitteiden näkökulmasta ja niitä hyödynnetään aktiivisesti osaksi omaa ammatillista kasvua ja tulevassa ammatissa työskentelyn taitoja (Husebo ym. 2013; Lavoie ym. 2015). Oppimiskeskustelussa simulaation toimijat, havainnoijat ja opettaja keskustelevat turvallisessa ilmapiirissä siitä, mitä simulaatiossa tapahtui, ja tarkastelevat 
tilannetta analyyttisesti. Tällainen avoin ja luottamuksellinen keskustelu auttaa oppijoita tiedostamaan, missä simulaatiossa onnistuttiin ja mitä asioita olisi voinut tehdä toisin. (Dreifuerst 2012; Dufrene \& Young 2014.)

\section{Moniammatillinen SIMULAATIO-OPPIMINEN}

Moniammatillisessa oppimisessa ylitetään erilaisia rajoja ja toimitaan substanssialueiden rajapinnoilla. Ylitettävät rajat voivat olla paitsi asiantuntijuuksiin ja osaamiseen liittyviä, myös kulttuurisia, asenteellisia, asiakkaan asemaan liittyviä tai rakenteellisia (Kekoni ym. 2019). Moniammatillista työtä sekä moniammatillista koulutusta koskevissa tutkimuksissa tuodaan usein esiin, että ammattilaiset eivät tunne toistensa työtehtäviä tai ammatillisia tulokulmia asiakkaan tilanteeseen riittävän hyvin, mikä saattaa asettaa yhteistyölle haasteita. Monitieteiset työryhmät saattavat näyttäytyä löyhinä yhteenliittyminä, ilman että asiantuntemukset sulautuvat niissä toisiinsa. (Mikkeli \& Pakkasvirta 2007; Isoherranen 2005; Mönkkönen ym. 2019; Mönkkönen \& Kekoni 2020.)

Yhteisellä oppimisella on tutkimuksissa todettu olevan keskeinen merkitys myös moniammatillisen osaamisen kehittymiselle. Opiskelijat oppivat tuntemaan toistensa ammattialoja ja ratkomaan ongelmia yhdessä, jolloin heidän ammatillinen osaamisensa laajenee suhteessa toisten ammattilaisten työhön ja yhteistyön kysymyksiin. (esim. Äikäs ym. 2020; Mönkkönen ym. 2019.) Moniammatillisuuden oppimisessa on kyse sekä yksilöllisestä että yhteisöl- lisestä oppimisesta. Yksilön ominaisuutena moniammatillisuus edellyttää muun muassa yhteistyöhön myönteisiä asenteita, päätöksenteko- ja ongelmanratkaisutaitoja ja sosiaalisen kanssakäymisen taitoja (esim. Hibbert ym. 2016). Yhteisöllisyys taas rakentuu erilaisuuden kunnioittamisen, yhteisöllisen motivaation ja moniammatillisten taitojen oppimisesta, mikä tapahtuu vuorovaikutuksessa toisten kanssa ja yhteisiin tavoitteisiin sitoutumisen avulla (Labrague ym. 2018). Jotta moniammatillisen yhteistyön osaaminen kehittyy, tarvitaan sen ydinosaamisen systemaattista, monitieteistä opetusta eri koulutus- ja ammattialojen välillä. Terveys- ja sosiaalialan koulutuksissa on kuitenkin vain harvoin mahdollisuuksia harjoitella yhteistyötä ennen työhön siirtymistä, koska ammattilaisten koulutus tapahtuu pääasiassa omilla aloillaan (Costello ym. 2018; Khalili ym. 2013). Näyttää siltä, että sosiaali- ja terveysalan koulutuksilla ei ole selkeää yhteistä näkemystä siitä, miten ammattien väliseen asiantuntijuuteen opitaan. Myöskään sitä, mitkä ovat pedagogiset ja teoreettiset viitekehykset tai didaktiset käytänteet, ei ole selkeästi määritelty. (Murdoch ym. 2017; Stanley \& Stanley 2019.)

Moniammatillista oppimista voidaan toteuttaa eri tavoin, esimerkiksi yhteisillä luennoilla, ryhmätöillä, kliinisellä harjoittelulla, moniammatillisilla keskusteluilla ja simulaatioilla (Herrmann ym. 2015; Schramm ym. 2017). Moniammatilliset simulaatiot, joissa usean alan ammattilaiset harjoittelevat yhdessä todellisuutta vastaavissa tilanteissa, on todettu tehokkaiksi yhteistyön oppimisessa (Failla \& Macauley 2014). Simulaatioissa jäljitellään sosiaali- ja terveysalan asiakastilanteita ja nii- 
den tavoitteisiin sisältyy ammattialojen kompetenssien mukaisia sekä moniammatillisen yhteistyön teemoja (Costello ym. 2018). Siten niissä voidaan luontevasti ja turvallisessa ympäristössä harjoitella toimintaa, antaa ja saada palautetta sekä tukea yhteistä reflektointia (Bland ym. 2011; Weller ym. 2012). Simulaatio soveltuu hyvin muun muassa moniammatillisen vuorovaikutuksen ja tiimityön harjoitteluun (Liaw ym. 2014).

Kokemukset moniammatillisista simulaatioista ovat pääosin myönteisiä ja niihin osallistuneet ovat arvostaneet mahdollisuutta oppia todellisuuden kaltaisissa tilanteissa ja soveltaa teoriaa käytäntöön (Costello ym. 2018; Hovland ym. 2018; Wang \& Petrini 2017). Moniammatillinen yhteisoppiminen on tukenut laadukkaan hoidon oppimista ja potilaan tarpeiden priorisointia (Roberts \& Goodhand 2018; Smith ym. 2018). Osallistujat ovat myös kokeneet simulaatioiden lisänneen varmuutta omasta osaamisestaan, vankistaneen tietämystä toisten ammattiryhmien rooleista ja vastuista sekä auttaneen ymmärtämään eri ammattiryhmien merkityksen asiakkaan kokonaisvaltaisen hoidon kannalta (esim. Pinto ym. 2018; Zamjahn ym. 2018). Sosiaalityön ja hoitotyön opiskelijoiden moniammatillisissa simulaatioissa osallistujat raportoivat ymmärryksen toisesta alasta lisääntyneen erityisesti simulaatioiden reflektiokeskustelujen seurauksena. Lisäksi opiskelijat kertoivat oppineensa uutta tiimin dynamiikasta ja sen merkityksestä potilaan hoitoon. (Kuehn, Huehn \& Smalling 2017.)

Moniammatillinen simulaatio-oppiminen on tilannekohtaista yhteistyötä ja siksi jokainen opiskelijaryhmä ja yksit- täinen opiskelija kokemuksineen vaikuttaa siihen, millaiseksi oppimistilanne muodostuu. Muun muassa aikaisempi kokemus simulaatioista, työkokemus ja henkilökohtaiset ominaisuudet vaikuttavat opiskelijoiden kykyyn ja haluun oppia simulaatiossa (Bland \& Tobbell 2016; Lestari ym. 2016). Moniammatillinen simulaatio-opetus haastaa myös opettajien pedagogisia taitoja ja edellyttää hyviä yhteistoiminnallisen ryhmän ohjaamistaitoja sekä kykyä antaa rakentavaa palautetta (ASPiH 2017; Hellström ym. 2015). Turvallisessa ilmapiirissä käyty keskustelu auttaa opiskelijoita viemään opitun jatkossa osaksi omaa työtään. Simulaatiota ohjaavien opettajien onkin tärkeää hallita hyvin opettamansa aihe ja heillä on oltava kiinnostusta simulaatio-opetukseen ja sen kehittämiseen (Foronda ym. 2016). Opettajilla on oltava myös myönteinen näkemys moniammatillisesta työstä ja sen merkityksestä eri alojen välisenä oppimistavoitteena (Stanley \& Stanley 2019).

Tavallisesti simulaatiot toteutetaan pienissä, muutaman henkilön ryhmissä tai ryhmissä, joissa on noin 20-30 henkilöä (Hooper ym. 2015; Rode ym. 2016). Yksi este simulaatioiden nykyistä suuremmalle käytölle moniammatillisessa opetuksessa on niihin tarvittava aika. Suurissa ryhmissä toistoja moniammatillisten simulaatioiden järjestämiseen tarvitaan runsaasti,jotta kaikki opiskelijat pääsevät osallistumaan harjoituksiin. Tämän lisäksi tarvitaan systemaattinen tilojen allokointi sekä eri oppilaitosten opiskelijoiden ja henkilöstön työajan suunnittelu. Vaikeuksia voi aiheuttaa myös se, miten simulaatiot integroidaan osaksi erilaisia opetussuunnitelmia tai miten moniammatillisten oppimista- 
pahtumien suunnitteluun ja ohjaamiseen tarvittava työ voidaan jakaa tasapuolisesti eri ammattialojen kesken (Foronda ym. 2016; Stanley \& Stanley 2019). Monitieteisessä opetuksessa valmistelu tuleekin aloittaa hyvissä ajoin, jotta opetussuunnitelmien aikataulut saadaan sovitettua yhteen. Tutkimuksia moniammatillisen simulaatio-opetuksen toteutuksesta suurille, yli 100 oppijan ryhmille on toistaiseksi hyvin vähän, kuten myös tietoa siitä, miten osallistujat kokevat oppimisen suursimulaatioissa (Saaranen ym. 2020).

\section{SuURSimulaAtioIDEN TOTEUTUS}

Suursimulaatio on uudentyyppinen simulaatio-oppimisen menetelmä, jossa perinteistä pienryhmäsimulaatiopedagogiikkaa sovelletaan hieman mukaillen suuremmalle oppijajoukolle. Olemme päätyneet nimeämään tätä simulaatiotyyppiä suursimulaatioksi, sillä mielestämme se kuvaa hyvin simulaation laatua. Suurryhmäsimulaatio voisi viitata perinteisen simulaatio-oppimisen niin kutsuttuun full scale (scenario based simulation) -tyyppiin, jossa harjoituksiin osallistuva ryhmä vain olisi pienryhmää suurempi. Suursimulaatio kuitenkin kuvaa mielestämme paremmin tilannetta, jossa heterogeeninen joukko oppijoita on seuraamassa havainnoijina dramatisoitua simulaatioharjoitusta, ja osallistuu siihen aktiivisen havainnoinnin ja oppimiskeskustelun kautta. Suursimulaatioita on toteutettu Itä-Suomen yliopistossa syksystä 2017 alkaen farmasian, hammaslääketieteen, hoitotieteen, lääketieteen ja yhteiskuntatieteellisten alojen sekä oppimis- ja tietotekniikkatukipalveluiden, Savonia- ammattikorkeakoulun terveysalan,
Karelia -ammattikorkeakoulun sosiaalialan ja Kuopion yliopistollisen sairaalan (KYS) yhteistyöhankkeena.

Suursimulaatio on oppimistilanne, jossa simulaatio toteutetaan ammattilaisten ja näyttelijöiden toimesta. Simulaation jälkeen seuraa opettajan vetämä oppimiskeskustelu, jossa kaikki simulaatioharjoituksessa toimijoina mukana olleet henkilöt kokoontuvat keskustelemaan tapahtumien kulusta ja kokemuksistaan pohtien myös tilanteeseen liittyneitä haasteita. Suursimulaation havainnoijat osallistuvat keskusteluun osallistavilla kysymyksillä (hyödyntäen presemo(C) -työkalua) ja kommenttipuheenvuoroilla.

Ensimmäinen suursimulaatio toteutettiin Itä-Suomen yliopistossa vuonna 2017 aiheesta "Lapsen kuoleman kohtaaminen". Simulaation tavoitteena oli kehittää eri alojen työntekijöiden ja opiskelijoiden osaamista moniammatillisesta yhteistyöstä perheen kriisitilanteessa, lisätä ymmärrystä haastavista vuorovaikutustilanteista sekä moniammatillisesta tiimityöstä ja saada kokemus simulaatio-oppimisesta osaamisen kehittämisessä. Simulaatiossa esitettiin tapahtumasarja lapsen kätkytkuoleman toteamisesta ja menettelytavoista eri ammattiryhmien työskentelyn muodostamana jatkumona. Luentosalin etualalle oli lavastettu perheen koti,jossa lapsen äitiä ja isää esittävät näyttelijät löysivät lapsensa elottomana sängystään. Hätänumeroon soittamisen jälkeen paikalle saapui ensihoitoyksikkö, jonka toimijoita esittivät alan ammattilaiset. He elvyttivät lasta ja soittivat konsultaatiopuhelun lääkärille, mutta lapsi todettiin lopulta kuolleeksi. Tämän jälkeen paikalle saapui poliisiyksikkö sekä sosi- 
aalipäivystyksen sosiaalityöntekijä, joita myös esittivät oikeat ammattilaiset. Poliisit tutkivat kuolemantapausta omasta ammatillisesta näkökulmastaan, ja sosiaalityöntekijä tarjosi vanhemmille välitöntä tukea, kriisiapua ja ohjausta tukipalveluihin. Sosiaalityön opiskelijoille oli tärkeä tunnistaa sosiaalipäivystyksen rooli akuutissa tilanteessa, sillä opintojen aikana akuutteja kriisejä tarkastellaan varsin vähän erityisesti sosiaalityön kannalta.

Toinen suursimulaatio toteutettiin marraskuussa 2018 aiheesta "Lääkehoidon haasteet iäkkäiden kotihoidossa". Vuoden 2018 simulaatio toteutettiin kaksivaiheisena niin, että ensin simuloitiin kotikäynti iäkkään asiakkaan luona ja tämän jälkeen moniammatillinen palaveri kotipalveluiden toimintayksikössä. Kotikäynnillä asiakasta esitti terveysalan opettaja ja hänen luonaan kotikäynnillä olevia henkilöitä (sairaanhoitajaa ja farmaseuttia) näiden alojen ammattilaiset. Kotikäynnin tilaksi oli lavastettu iäkkään asiakkaan koti,ja keskustelussa käytiin läpi hänen elämäntilannettaan ja lääkitystään. Kahvitauon aikana tilan lavastus vaihdettiin simulaation toista osaa varten kokoustilaksi, jossa monialainen palaveri järjestettiin. Palaveriin osallistui edellä mainittujen ammattialojen lisäksi myös ravitsemusterapeutti ja lääkäri, ja sen tavoitteena oli käsitellä asiakkaan monialaista hoito- ja palvelusuunnitelmaa. Palaveri oli lääkärijohtoinen ja keskittyi asiakkaan lääkehoidon läpikäymiseen niin, että lääkelista oli heijastettu luentosalin valkokankaalle, ja sitä käytiin keskustelussa läpi. Kaikki palaveriin osallistuvat pääsivät mukaan tuottamaan näkemyksiä iäkkään asiakkaan hoidon ja palveluiden suunnitteluun. Myös sosiaalityön- tekijän oli tarkoitus osallistua palaveriin, mutta sairastumisen takia hän jäi puuttumaan osallistujien joukosta.

Suursimulaatioihin osallistui oppijoina terveys- ja sosiaalialan opiskelijoita ammattikorkeakouluista sekä terveystieteiden, yhteiskuntatieteiden ja humanististen alojen yliopisto-opiskelijoita. Tämän lisäksi simulaatioihin osallistui sosiaali- ja terveysalojen ammattilaisia. Vuoden 2017 simulaatiossa osallistujia oli noin 430, joista osa osallistui videovälitteisesti Karelia- ja Savoniaammattikorkeakouluista sekä Kuopion yliopistollisesta sairaalasta.Vuoden 2018 simulaatioon, jonka aihe oli tarkemmin rajattu, osallistui noin 200 opiskelijaa ja eri alojen ammattilaista, eikä etäyhteyksiä ollut järjestetty.

\section{OPISKELIJOIDEN REFLEKTIOT LAADULLISEN SISÄLLÖNANALYYSIN AINEISTONA}

Artikkelin aineistona ovat sosiaalityön ja sosiaalipsykologian opiskelijoiden yksilöreflektiot oppimisestaan suursimulaatioissa. Analysoitavia reflektiota oli yhteensä 58 , joista 28 oli vuodelta 2017 ja 30 vuodelta 2018. Sosiaalipsykologian opiskelijoiden tuottamia reflektioita oli 11 ja sosiaalityön opiskelijoiden kirjoittamia 47. Reflektioita oli tuotettu kahdella temaattisesti moniammatillisuuteen kiinnittyvällä syventävän vaiheen monialaisella opintojaksolla, joihin suursimulaatio kuului joko livesimulaationa (vuonna 2017) tai sekä tallenteena että livesimulaationa (vuonna 2018). Tehtävänantona molemmilla opintojaksoilla oli pohtia ja reflektoida yksilöesseessä, mitä moniammatillisesta työskentelystä opittiin suursimulaatiossa sekä arvioida suursimulaatiota 
oppimiskokemuksena. Lupaa käyttää reflektioita tutkimusaineistona kysyttiin kaikilta yhteensä 69:1tä edellä mai- nituille kursseille vuosina 2017-2018 osallistuneilta opiskelijoilta, ja lupa saatiin 58:1tä opiskelijalta.

Taulukko 1. Sisällönanalyysin käsitteet sekä ala-, ylä- ja pääluokat.

\begin{tabular}{|c|c|c|c|}
\hline käsite & alaluokka & yläluokka & pääluokka \\
\hline $\begin{array}{l}\text {-moniammatillinen työskentely vaatii rohkeutta } \\
\text { (yhteistyöhön ja tuoda oma ammatillinen näkökulma } \\
\text { esiin) } \\
\text {-vaatii positiivista asennetta yhteistyöhön } \\
\text {-vaatii kiinnostusta ja luottamista toisten } \\
\text { ammattiryhmien työhön } \\
\text {-täytyy olla riittävä ymmärrys muiden } \\
\text { ammattiryhmien osaamisesta } \\
\text {-vaatii oman osaamisen reflektointia } \\
\text {-vaatii jatkuvaa kouluttautumista }\end{array}$ & $\begin{array}{l}\text { Yksilöön liittyvät } \\
\text { ominaisuudet }\end{array}$ & $\begin{array}{l}\text { Moni- } \\
\text { ammatillisuuden } \\
\text { vaatimukset }\end{array}$ & $\begin{array}{l}\text { Oppimiskokemukset } \\
\text { moni- } \\
\text { ammatillisuudesta }\end{array}$ \\
\hline $\begin{array}{l}\text {-täytyy osata tunnistaa yhteiset tavoitteet } \\
\text { työskentelylle } \\
\text {-täytyy osata sovittaa yhteen eri asiantuntijuuksia } \\
\text {-vaatii hyviä vuorovaikutustaitoja (myös } \\
\text { vuorovaikutuksen mikroelementtien hallintaa) } \\
\text {-vaatii selkeitä rooleja ja työnjakoa }\end{array}$ & $\begin{array}{l}\text { Yhteistyö- ja } \\
\text { vuorovaikutus- } \\
\text { taidot }\end{array}$ & & \\
\hline $\begin{array}{l}\text {-vaatii vahvaa johtajuutta } \\
\text {-vaatii kykyä jaettuun johtamiseen } \\
\text {-vaatii riittäviä taloudellisia resursseja } \\
\text {-vaatii riittäviä ajankäytöllisiä resursseja } \\
\text {-vaatii työelämän tämänhetkisiin ongelmiin } \\
\text { puuttumista }\end{array}$ & $\begin{array}{l}\text { Rakenteet ja } \\
\text { resurssit }\end{array}$ & & \\
\hline $\begin{array}{l}\text {-edistää asiakaslähtöisyyttä } \\
\text {-asiakkaan kokemus kuulluksi tulemisesta vahvistuu } \\
\text {-edistää kokonaisvaltaisen näkemyksen syntymistä } \\
\text { asiakkaan tilanteesta }\end{array}$ & $\begin{array}{l}\text { Asiakas tulee } \\
\text { työskentelyn } \\
\text { keskiöön }\end{array}$ & $\begin{array}{l}\text { Moni- } \\
\text { ammatillisuuden } \\
\text { hyödyt }\end{array}$ & \\
\hline $\begin{array}{l}\text {-edistää tiedonkulkua } \\
\text {-vastuu jakautuu useammalle ammattilaiselle } \\
\text {-voimavaroja yhdistävä työskentelyote } \\
\text {-uuden oppiminen muilta ammattilaisilta }\end{array}$ & $\begin{array}{l}\text { Työskentelyn } \\
\text { laatu paranee }\end{array}$ & & \\
\hline $\begin{array}{l}\text {-moniammatillisten tilanteiden havainnollistuminen } \\
\text {-tunteet mukana oppimisessa } \\
\text {-tieteenalojen ylittäminen ja aito monialainen opetus } \\
\text { mahdollistuu }\end{array}$ & $\begin{array}{l}\text { Suursimulaatio- } \\
\text { oppimisen } \\
\text { vahvuudet }\end{array}$ & $\begin{array}{l}\text { Simulaatio- } \\
\text { oppimisen } \\
\text { vahvuudet ja } \\
\text { siihen } \\
\text { vaikuttavat } \\
\text { tekijät }\end{array}$ & $\begin{array}{l}\text { Havainnot } \\
\text { suursimulaatio- } \\
\text { oppimisesta }\end{array}$ \\
\hline $\begin{array}{l}\text {-oma aiempi osaaminen vaikuttaa siihen, mitä } \\
\text { simulaatiossa opitaan } \\
\text {-opiskelijan kiinnostuksen kohteet vaikuttavat } \\
\text { oppimiseen suursimulaatiossa }\end{array}$ & $\begin{array}{l}\text { suursimulaatio- } \\
\text { oppimiseen } \\
\text { vaikuttavia } \\
\text { asioita }\end{array}$ & & \\
\hline
\end{tabular}


Tutkimuskysymyksemme ovat: 1) mitä opiskelijat oppivat suursimulaatiossa moniammatillisesta työskentelystä? sekä 2) Millaisia havaintoja opiskelijat tekevät suursimulaatio-oppimisesta? Aineisto on analysoitu aineistolähtöisen sisällönanalyysin menetelmää käyttäen. Sisällönanalyysissa pyritään aineiston merkitysten kuvaamiseen koodaamalla ja ryhmittelemällä järjestelmällisesti merkittävät tekijät omiksi luokikseen (esim.Tuomi \& Sarajärvi 2018; Schreier 2012). Aineiston analyysi toteutettiin lukemalla aineistoa useaan kertaan läpi niin, että havaittiin, mitkä asiat tuottivat vastauksia tutkimuskysymyksiin. Näin tavoitetut alkuperäisilmaukset ryhmiteltiin sisällöllisesti samaan teemaan liittyviksi käsitteiksi. Käsitteitä edelleen analysoimalla ja tiivistämällä sekä keskenään vertailemalla rakennettiin analyysin alaluokat. Nämä tiivistettiin edelleen yläluokiksi ja lopulta kahdeksi pääluokaksi, jotka kuvaavat opiskelijoiden oppimiskokemuksia moniammatillisuudesta ja havaintoja simulaatiooppimisesta.

\section{OPISKELIJOIDEN OPPIMISKOKEMUKSET MONIAMMATILLISUUDESTA}

Ensimmäisenä etsimme vastausta kysymykseen, mitä opiskelijat oppivat suursimulaatioissa sen keskeisenä sisältönä olleesta moniammatillisuudesta. Opiskelijoiden oppimiskokemukset jakautuivat kahteen yläluokkaan. Ensimmäinen yläluokka "moniammatillisuuden vaatimukset" rakentui huomioista moniammatillisuuden edellyttämästä erityisosaamisesta.

Suursimulaatio oli selvästi herättänyt ajatuksia moniammatillisuudesta taitoja vaativana työskentelynä, joka on enemmän kuin pelkkää yhteistyötä. Opittiin, että moniammatillisuus vaatii sekä työntekijältä että työyhteisöltä riittäviä tietoja ja taitoja sekä esimerkiksi ajallisia ja taloudellisia resursseja. Yksilöön liittyvistä ominaisuuksista nousi esille rohkeus tehdä yhteistyötä muiden alojen ammattilaisten kanssa ja tuoda omaa ammatillista näkökulmaa esille yhteistyössä. Lisäksi tärkeänä pidettiin positiivista asennetta yhteistyöhön, kuten opiskelija seuraavassa lainauksessa pohtii.
Moniammatillisessa yhteistyössä jokai- sen osallistujan omalla asenteella on suuri merkitys. Jos joku taho ajattelee tietävänsä asiat paremmin kuin muut tai laistaa vas- tuustaan niin yhteistyö ei onnistu. Samoin työryhmässä tai tiimissä vaaditaan jokaisel- ta kykyä kuunnella muita, reflektoida omaa toimintaa ja taitoa asettua toisen asemaan.

Joissakin reflektioissa kerrottiin oman asenteen moniammatillisuutta kohtaan muuttuneen aikaisempaa positiivisemmaksi simulaatioiden seurauksena, mikä on todettu aiemmissakin tutkimuksissa erääksi tärkeimmistä moniammatillisen koulutuksen vaikutuksista (esim. Pinto ym. 2018). Myös luottamus toisten tekemää työtä kohtaan oli lisääntynyt. Vaatimus luottamukseen eri alojen välillä tulee esille myös monissa aiemmissa tutkimuksissa moniammatillisuudesta (Hibbert ym. 2016; Bronstein 2003).

Reflektiossa kuvattiin moniammatillisuuden vaativan riittävää ymmärrystä toisten alojen työstä. Kun työntekijällä on riittävä tieto siitä, mitä toisten ammattialojen tehtäviin ja asiantuntemukseen sisältyy, osaavat he joustavasti hyödyntää näiden alojen osaamista moniammatillisessa yhteistyössä. Oppimisen kannalta 
olivat tärkeitä osallistujien kokemukset, joissa kerrottiin aiempien jopa virheellisten käsitysten toisten ammattilaisten työstä muuttuneen.

Tarve oman ammatillisen osaamisen jatkuvaan reflektointiin osana moniammatillista työskentelyä tuotiin myös esiin. Tämä vaatii taitoja reflektoida omaa työtä, osaamista ja sen suhdetta toisiin aloihin. Lisäksi todettiin, että moniammatillisuus vaatii jatkuvaa halua kehittää omaa osaamista ja tämän myötä myös kouluttautumista moniammatillisiin taitoihin. Nämä havainnot kiinnittyivät opiskelijareflektioissa paitsi opiskelun aikaiseen moniammatilliseen oppimiseen, myös työelämässä edelleen tapahtuvaan oppimiseen. Opiskelijat ymmärsivät moniammatillisten taitojen kehittyvän myös kokemuksen karttuessa, kuten pohditaan esimerkiksi seuraavassa lainauksessa.

Moniammatillinen yhteistyö on ammatillisen osaamisen alue, josta on mahdollista oppia jatkuvasti lisää. Moniammatillisen $y$ hteistyön taidot eivät tule koskaan valmiiksi, vaan kehittyvät kokemuksen kautta.

Reflektioissa kuvattiin moniammatillisen työskentelyn vaativan myös vahvoja yhteistyö- ja vuorovaikutustaitoja. Opiskelijat kuvasivat tällaisina taitoina muun muassa kykyä tunnistaa $y$ hteiset tavoitteet työskentelylle ja sovittaa yhteen eri asiantuntijuuksia. Tässä yhteydessä asiantuntijuuksien yhteensovittamista kuvattiin enemmänkin vuorovaikutustaitojen kuin tiedollisen osaamisen näkökulmasta. Reflektioissa saatettiin myös pohtia yksityiskohtaisia vuorovaikutukseen liittyviä elementtejä, joita suursimulaatiota seuratessa oli havaittu.
Näitä kuvaillaan seuraavassa lainauksessa:
Toinen hieman silmään pistävä elementti keskustelussa oli erään ammattilaisen tapa toisinaan huokailla asiakkaan hieman eksy- essä aiheesta tai tämän kertoessa elämänta- voistaan. Vaikka nämä mikroilmeet ja -eleet olivat lähes huomaamattomia, herättivät ne ainakin oman huomioni. Toisaalta työnte- kijät hyödynsivät paljon myös positiivisia mikroilmeitä, esimerkiksi nyökyttelivät, hy- myilivät ja nojautuivat asiakasta päin.

Opiskelijareflektioista voikin päätellä, että suursimulaatiot ovat erityisesti vuorovaikutuksen oppimiseen sopiva menetelmä. Seuraamalla simulaatiota havainnoijana voi vuorovaikutuksesta ja sen mikroelementeistä havaita jopa enemmän, kuin osallistumalla itse perinteiseen pienryhmäsimulaatioon. Edellisten lisäksi opiskelijat kuvasivat moniammatillisessa yhteistyössä tärkeänä seikkana selkeätä työnjakoa, mikä on aiemmissakin simulaatio-oppimista koskevissa tutkimuksissa noussut esille (esim. Costello ym. 2018; Wang \& Petrini 2017). Ammattirooleihin liittyvän työnjaon merkitystä kuvattiin usein pohdinnoissa, joissa kerrottiin moniammatillisen yhteistyön vaativan toimijoiltaan selkeitä rooleja.

Ensihoitajat pyrkivät pelastamaan vauvan, poliisin tehtävä oli tutkia, onko mahdollista rikosta tapahtunut ja sosiaalityöntekijä pyrki tukemaan vanhempia ja auttamaan heitä järkyttävässä tilanteessa. Selkeää tässä moniammatillisessa yhteistyössä oli minun mielestäni juuri se, että kaikki ammattilaiset tavoittelivat tilanteen eteenpäin viemistä ja tilanteen sujuvaa hoitamista. 
Paitsi yksilöön ja yhteistyöhön liittyviä taitoja ja tiedollista osaamista, opiskelijat kuvasivat moniammatillisen yhteistyön vaativan myös taloudellisia, ajallisia ja työn organisointiin liittyviä rakenteita, joissa moniammatillinen työskentely mahdollistuu. Moniammatillisuuden nähtiin vaativan vahvaa johtajuutta, mutta myös kykyä jaettuun johtamiseen. Toisaalta kummassakaan simulaatiossa moniammatilliseen työskentelyyn liittyvä johtaminen ei ollut keskiössä. Myös riittävät taloudelliset, ja ajankäytölliset resurssit mainittiin reflektioissa. Moniammatillisuuden nähtiin vaativan aikaa, pysähtymistä ja läsnäoloa, jotka eivät mahdollistu, ellei työskentelylle ole esimerkiksi riittäviä ajallisia resursseja. Joissakin reflektioissa tuotiin esille myös tämänhetkisiä sosiaali- ja terveysalan työn organisointiin liittyviä ongelmia, kuten jatkuva kiire, uupuminen ja työntekijöiden nopea vaihtuvuus. Näiden tunnistettiin olevan rakenteellisia ongelmia, jotka osaltaan viestivät työelämän tilasta, jossa myöskään moniammatillinen yhteistyö ei parhaalla mahdollisella tavalla toteudu. Tätä pohditaan seuraavassa lainauksessa:

Moniammatillisen yhteistyön onnistumista ei voikaan jättää $\gamma k s i n o m a a n ~ y k s i t t a ̈ i s-$ ten työntekijöiden taitojen varaan, vaan se edellyttää toimivia rakenteita ja resursseja. Yhteistyön järjestämiseen ja organisoimiseen on monia tapoja, mutta tärkeintä on mahdollistaa joustava yhteistoiminta, jossa jokaisen on mahdollista hyödyntää muiden osaamista ja muiden alojen asiantuntemusta myös omassa työskentelyssään.

Moniammatillisuuden vaatimusten ohella opiskelijat huomasivat suursimulaatiota havainnoidessaan, että moniammatillisuuteen liittyy runsaasti hyötyjä. Asiakkaalle koituvista hyödyistä opiskelijat nostivat esille, että moniammatillisuus edistää asiakaslähtöisyyttä. Suursimulaatioissa opiskelijat olivat havainneet, että asiakas tulee moniammatillisessa työskentelyssä eri tavoin työn keskiöön, kuin perinteisessä, yhden ammattilaisen toteuttamassa työskentelyssä. Asiakkaan roolin kuvattiin olevan siinä isompi ja merkityksellisempi kuin muussa sosiaali- ja terveysalan työssä. Myös moniammatillisessa työskentelyssä syntyvä kokonaisvaltainen näkemys asiakkaan tilanteesta kuvattiin reflektioissa yhtenä asiakkaan tilanteeseen vaikuttavana moniammatillisen työskentelyn hyötynä. Simulaatioissa opiskelijoille syntyi oppimiskokemus siitä, että yhdessä eri ammattiryhmät pystyvät luomaan laajemman kuvan asiakkaan elämäntilanteesta, ja näin ollen myös tehokkaammin suuntaamaan työskentelyään tärkeimmiksi koettuihin ongelmiin. Asiakkaan parempi kuulluksi tuleminen nostettiin myös esille moniammatillisuuden hyötynä. Suursimulaatiossa (erityisesti jälkimmäisessä, jossa moniammatillisen työskentelyn keskiössä oli iäkäs asiakas ja tämän lääkehoidon haasteet) oli havaittu käytännössä, että toimivassa moniammatillisessa kohtaamisessa myös asiakas saa merkityksellisen kokemuksen autetuksi tulemisesta ja kunnioittavasta ja kuuntelevasta kohtaamisesta.

Uusi näkökulma itselle oli, kuinka moniammatilliset palvelut voivat myös kasvattaa asiakkaan halua ja valmiutta ottaa apua vastaan, ja tuottaa kokemusta kuulluksi tulemisesta, kun asiakkaan elämäntilanne ja tarpeet otetaan huomioon kokonaisuutena.

Moniammatillisuudesta huomattiin olevan hyötyä myös sosiaali- ja terve- 
ysalan työlle, sen laadulle ja tekijöille. Opiskelijat nostivat esille havaintoja tiedonkulun paranemisesta, voimavarojen yhdistämisestä sekä muiden alojen ammattilaisilta oppimisesta työskentelyn laatuun vaikuttavina tekijöinä. Moniammatillisuutta koskevissa tutkimuksissa on usein esitetty näitä seikkoja yhteisen työskentelyn peruslähtökohdiksi (esim. Blakey 2014). Samanaikaisesti kun työn laatu paranee, tuottaa moniammatillinen työote hyötyjä myös työntekijöille ja työyhteisölle. Reflektioissa esiin nostettuja asioita olivat vastuun jakautumiseen liittyvät kysymykset ja tämän merkitys esimerkiksi työssä jaksamiselle. Myös työyhteisön ymmärrettiin hyötyvän siitä, että voimavaroja kyettäisiin yhdistämään ja yksittäisen työntekijän taakkaa vähentämään, kuten seuraavassa sitaatissa todetaan:

\section{Mielestäni moniammatillisen yhteistyön rikkaus on se, että asioita voidaan tarkas- tella eri näkökulmista. Muilta ammattilai- silta voi saada tukea ja neuvoa vaikeassa tilanteessa. (...). Yhteistyötä ei pidä nähdä uhkana omalle ammattitaidolle, vaan antaa tilaa myös toisenlaisista lähtökohdista tule- valle tiedolle. Koen moniammatillisuuden myös hyvin järkeväksi työskentelytavaksi, koska sillä voidaan välttää päallekkäisen työn tekeminen.}

Opiskelijat kokivat moniammatillisuuden hyödyntävän monella tavoin paitsi työntekijöitä, myös asiakkaita. Moniammatillisuudesta suursimulaatiossa opitut asiat olivat paljolti sen kaltaisia, mitä moniammatillisuuden hyödyistä ja vaatimuksista tiedetään aiemman tutkimuksen perusteella (esim. Costello ym. 2018; Wang \& Petrini 2017; Äikäs ym. 2020). Huomionarvoista on, että tässä tutkimuksessa opiskelijoiden oppimis- kokemukset syntyivät oppimistilanteissa, joissa opiskelijat havainnoivat dramatisoitua moniammatillista tilannetta ja siihen liittyvää oppimiskeskustelua.

\section{OPISKELIJOIDEN HAVAINNOT SUURSIMULAATIOSTA OPPIMISMENETELMÄNÄ}

Opiskelijoiden oppimisreflektioissa pohdittiin myös oppimista suursimulaation keinoin.Tämä on tutkimuksellisesti erityisen kiinnostavaa, sillä tietääksemme vastaavia simulaatioita ei ole sosiaali- ja terveysalan koulutuksissa aiemmin toteutettu, emmekä ole onnistuneet löytämään aiempaa olemassa olevaa tutkimusta vastaavantyyppisistä suursimulaatioista. Opiskelijat huomasivat, että suursimulaatio on hyvä keino havainnollistaa yliopisto-opetuksessa usein melko teoreettisiksi jääviä asioita, koska suursimulaatio edisti tunteiden vahvaa merkitystä oppimisessa ja tuotti aitoa tieteenalarajoja ylittävää oppimista.

Suursimulaatiota pidetiin oppimisen näkökulmasta hyvänä keinona havainnollistaa ja konkretisoida teoreettisia ilmiöitä. Monet opiskelijat kuvasivatkin vasta simulaatioon osallistuttuaan ymmärtäneensä, mitä moniammatillisuus käytännössä tarkoittaa. Toisaalta niille opiskelijoille, joille moniammatillisuus oli oman työkokemuksen kautta jo tuttua, oppimiskokemukset suursimulaatiossa liittyivät esimerkiksi vuorovaikutuksen pieniin yksityiskohtiin Suursimulaatiota aitoja moniammatillisia tilanteita hyvin havainnollistavana tilanteena kuvattiin aineistossa esimerkiksi seuraavalla tavoin: 
Kurssin aikana tuli pohdittua moniammatillisen yhteistyön peruslähtökohtia meidän alalla. Simulaatiotehtävät olivat yllättävän lähelle tulevia ja havainnollistivat todella hyvin tilanteita, joissa moniammatillista työtä tehdään.

Perinteistä simulaatio-oppimista pidetään hyvänä opetusmenetelmänä esimerkiksi integratiivisen pedagogiikan näkökulmasta, jossa tunteiden ymmärretään olevan sosiaalisten ja tiedollisten seikkojen ohella merkityksellisiä oppimisessa (esim. Tynjälä ym. 2016). Tunteet tulivat esille useassa opiskelijareflektiossa myös suursimulaatio-oppimiseen liittyen. Etenkin lapsen kuoleman kohtaaminen -suursimulaatio oli sensitiivinen, ja opiskelijat pohtivat reflektiossaan siinä heränneitä tunteita ja niiden merkitystä oppimiselleen.

En varmasti unohda kyseistä kokemusta koskaan, ja tulen siitä puhumaan varmasti myös muille. Myös roolijaot konkretisoituivat silmien edessä, ja vanhempien reaktiot tallentuivat varmaan ikuisiksi ajoiksi muistiin, vaikka näyteltyjä olivatkin. Olen aika varma, että jos ikinä päädyn sosiaalityöntekijänä samanlaiseen tilanteeseen, ammennan tästä kokemuksesta paljon varmuutta.

Vahva emotionaalinen kokemus suursimulaatiossa saikin monet opiskelijoista pohtimaan omien tunteiden merkitystä yleisemmin kriisitilanteissa tai muutoin tulevassa työnkuvassa. Tämä nosti esiin muun muassa kysymyksen ammatillisuudesta suhteessa omien tunteiden näyttämiseen. Esille nousseet tunteet suursimulaation aikana sekä niiden reflektointi jälkeen päin auttoivat opiskelijoita pohtimaan tunteita laajasti osana tulevaa ammattiaan ja ammatillisuuttaan. Tässä mielessä suursimulaation ja erityisesti tunteiden hyödyntämisen suursimulaatio-oppimisessa voidaan todeta edistävän keskustelua sellaisista teemoista, joita ei välttämättä perinteisessä opetuksessa tyypillisesti käsitellä. Suursimulaatiossa dramatisoitua simulaatioharjoitusta seuratessa saattaa tunteiden kokemiselle olla jopa enemmän tilaa ja mahdollisuuksia kuin perinteisessä pienryhmäsimulaatiossa, koska perinteisemmässä simulaatio-opetuksessa huomio kiinnittyy vahvemmin tiedollisiin ja taidollisiin oppimistavoitteisiin. Suursimulaatiossa omien tunteiden reflektoinnille jää enemmän tilaa.

Opiskelijat totesivat reflektioissaan, että suursimulaatiot edistivät oppimista moniammatillisuudesta. Toisaalta havaittiin myös se, että yhtäältä oma aiempi osaaminen ja koulutusala ja toisaalta opiskelijan omat kiinnostuksen kohteet vaikuttavat siihen, mitä ja miten simulaatioista oppii. Kaikkien oppijoiden oppimiskokemukset suursimulaatiosta eivät ole samanlaisia, mikä on todettu myös aikaisemmassa tutkimuksessa simulaatio-oppimisesta (Bland \& Tobbell 2016; Lestari ym. 2016). Opiskelijat pohtivat muun muassa sitä, että suursimulaatiossa huomio helposti kiinnittyy juuri siihen ammattilaiseen, jonka edustamaa alaa itse opiskelee. Tällöin kokonaisuuden havainnointi ja esimerkiksi työntekijöiden välisen vuorovaikutuksen havainnointi voi jäädä vähemmälle, mikä ei välttämättä ole suursimulaatiossa tavoiteltavaa. Edellä mainittuja seikkoja pohditaan reflektioissa esimerkiksi seuraavasti:

Kun simulaatiota seuraa tapahtuman ulkopuolelta, herättää se tunteita ja ajatuksia ihan eri tavalla kuin jos olisi itse läsnä. Mutta osaako katsoa niin ettei tuomitse tai 
arvota työntekijöiden panosta tapahtumassa? Helposti voi löytää virheitä ja toisin tekemisen kohtia. Se ei ole väärin mutta se antaa myös viitteitä, että ihmiset haluavat, että oman ammatin edustaja osaa hoitaa tilanteen optimaalisen hyvin ja edustaa ammattikuntaansa hyvin.

Edellä olevassa lainauksessa pohditaan myös, miten olennaisena kysymyksenä opiskelijat pitävät sitä, että moniammatillinen palaveri etenee mahdollisimman onnistuneesti ja miten "hyvin" kunkin alan ammattilainen oman roolinsa siinä hoitaa. Simulaation toteutuksessa voi tulla eteen suunnittelemattomia asioita, esimerkiksi tietyn ammattialan näyttelijän sairastuminen ja siitä syystä simulaatiosta pois jäänti, kuten toisessa opiskelijareflektioiden kohteena olevassa simulaatiossa kävi. On myös mahdollista, että simulaatiossa esitetty moniammatillinen palaveri ei toteudu niin, että kaikkien alojen ammattilaiset pääsisivät siinä ääneen. Tämä voi olla myös hyvä asia, sillä se, että kaikki ei mene täydellisesti, voi johdatella opiskelijaa pohtimaan seikkoja, joita täydellisesti toteutunut simulaatio ei lainkaan nostaisi esille.

Monialaisen simulaation järjestämistä pidettiin monessa opiskelijareflektiossa yleisemmin osoituksena siitä, että tieteenalakohtaisia rajoja on mahdollista korkeakouluopetuksessa ylittää. Moniammatillinen opetus on sosiaali- ja terveysaloilla edelleen enemmän poikkeus kuin sääntö, ja suursimulaatioon osallistuneet opiskelijat toivatkin esille ilahtuneita näkemyksiä siitä, että suursimulaatiossa oltiin aidosti moniammatillisen oppimisen äärellä.
Olenkin ylpeä tästä kurssista, kun siinä on hyödynnetty simulaatiopedagogiikkaa ja kurssin jälkeen voi tuntea, että on saanut hyvää oppia ja voi sanoa, että on tehty $y h$ teistyötä sosiaali- ja terveystieteiden välillä. Käytännössä on näytetty, että on mahdollista ylittää tiederajat opetuksessa. Työelämässä voisi ehdottaa, että simulaatio-oppimista hyödynnettäisiin myös kaupungin omassa täydennyskoulutuksessa.

Suursimulaatiot olivat aidosti monialaisesti toteutettua opetusta. Vaikka monialaisia kursseja jonkin verran jo onkin sosiaalityön ja sosiaalipsykologian opetuksessa, usein ne toteutetaan siten, että eri oppiaineiden sisällöt käydään läpi erillisillä luennoillaan eikä yhteistä opetusta ole välttämättä lainkaan. Suursimulaatio koettiin uudenlaisena, kokonaisvaltaisesti monialaisena opetuksena. Edellä olevassa sitaatissa opiskelija tuo esille myös työelämänäkökulmaa, mikä ilmentää osaltaan sitä, että moni opiskelija havainnoi suursimulaatiota paitsi opiskelijana myös sosiaalialan ammattilaisena.

\section{Pohdinta: moniammatillisuUtta VOI JA KANNATTAA OPETTAA SUURSIMULAATION KEINOIN}

Tutkimuksen tulosten perusteella voimme sanoa, että suursimulaatiot ovat tuottaneet merkittäviä oppimiskokemuksia sekä moniammatillisuudesta että suursimulaatio-oppimisesta. Moniammatillisuudesta opittiin, että se edellyttää monenlaista osaamista yksilöllisesti ja yhteistyöosaamisen näkökulmasta sekä yhteistyön mahdollistavia rakenteita. Lisäksi opittiin, että moniammatillisuudesta on hyötyä asiakkaalle, työntekijöille ja työskentelyn 
laadulle. Saman tyyppisiä tuloksia on todettu aikaisemmissakin tutkimuksissa (esim. Bronstein 2003; Bayne-Smith ym. 2014; Hibbert ym. 2016).

Suursimulaatiota tarkasteltiin tässä tutkimuksessa myös oppimistapana. Sen todettiin olevan hyvä tapa havainnollistaa moniammatillisia työskentelytapoja,joista opiskelijoilla saattoi olla vahvaakin teoreettista tietoa, mutta ymmärrys sen ilmenemisestä käytännössä saattoi puuttua lähes kokonaan. Integratiivisen pedagogiikan mukaisesti suursimulaatio-opetuksessa kyetään yhdistämään tiedollinen, käytännön ja tunteiden taso sekä näihin kiinnittyvät osaamisen ja asiantuntijuuden alueet (Tynjälä ym. 2016). Suursimulaatiota voidaankin pitää tehokkaana vuorovaikutus- ja moniammatillisten taitojen opetusmenetelmänä siksi, että suursimulaatioon havainnoijana osallistuessaan opiskelijalla on jopa perinteistä simulaatio-oppimista vahvemmin mahdollisuus kokea ja reflektoida oppimistilanteeseen liittyviä tunteita suhteessa tiedolliseen ja taidolliseen oppimiseen. Tämä seikka erottaa suursimulaatiooppimisen muusta simulaatio-oppimisesta, sillä tunteiden reflektointiin ei jää samalla tavoin aikaa silloin, kun harjoitukseen osallistutaan muussakin kuin havainnoitsijan roolissa.

Verrattuna pienryhmäsimulaatioon suursimulaatio näyttää tuottavan hyvin samantyyppisiä oppimistuloksia, vaikka opiskelijat eivät olekaan suursimulaatiossa toimijoina (Bambini 2016; Bland \& Tobbell 2016). Simulaation ja oppimiskeskustelun havainnointi sekä omien havaintojen esilletuominen yhteisessä keskustelussa ja oppimisreflektioissa mahdollistaa myös yhteisöllisen oppimisen tason toteutumisen suursimulaatiossa. Avoin ja luottamuksellinen keskustelu ja sen mahdollistama oppiminen voi toteutua suursimulaation oppimiskeskustelussa hyvin samantyyppisesti kuin se toteutuu pienryhmäsimulaatioissa (Dreifuerst 2012; Dufrene \& Young 2014).

Suursimulaatio mahdollistaa tämän tutkimuksen tulosten perusteella suhteellisen todentuntuisen kokemuksen simulaation aiheena olevasta moniammatillisesta tilanteesta, mikä on simulaatio-opetuksen keskeinen, kokemukselliseen oppimiseen perustuva pedagoginen lähtökohta (Eteläpelto ym. 2013; Kolb 1984). Perinteisen simulaatio-opetuksen tavoitteisiin kuuluu myös teoreettisten käsitteiden havainnollistaminen $\mathrm{ja}$ niiden tekeminen käytännön tasolla ymmärrettäviksi (Costello ym. 2018; Hovland ym. 2018; Wang \& Petrini 2017), mikä myös suursimulaatiossa on tutkimuksemme tulosten mukaan toteutunut varsin hyvin. Suursimulaatioiden voidaan todeta lisänneen opiskelijoiden ymmärrystä omasta roolistaan ja osaamisestaan osana moniammatillista työryhmää, vahvistaneen tietämystä toisten ammattiryhmien tehtävistä ja vastuista sekä edistäneen ymmärrystä eri ammattiryhmien merkityksestä asiakkaan kokonaisvaltaisen tuen ja hoidon näkökulmasta. Näitä näkökulmia on nostettu esille oppimistuloksina myös perinteisestä simulaatio-oppimisesta (esim. Pinto ym. 2018; Zamjahn ym. 2018).

Kuten aiemmassakin tutkimuksessa (Bland \& Tobbell 2016; Lestari ym. 2016), myös suursimulaatiossa kulloinenkin oppimistilanne osallistujineen vaikuttaa siihen, millaiseksi oppimis- 
tilanne milloinkin muodostuu. Esimerkiksi osallistujien ja tilaisuudesta vastuussa olevien tahojen aikaisempi kokemus simulaatio-oppimisesta ja -opetuksesta, osallistujien aiempi työkokemus ja niin simulaation osallistuvien ammattilaisten, sitä ohjaavien opettajien kuin opiskelijoidenkin yksilölliset ominaisuudet vaikuttavat siihen, mitä ja miten suursimulaatiosta opitaan. Moniammatillista opetusta on aihetta pedagogisesti mallintamaan pyrkivässä tutkimuksessa kuvattu myös alati "kaaoksen partaalla" toteutuvaksi ja monella tavoin kompleksiseksi kokonaisuudeksi, jonka esittäminen lineaarisena mallina on jopa mahdotonta (Cooper ym. 2004). Hyvin suunniteltu on puoliksi tehty, mutta moniammatillisessa opetuksessa on aina otettava huomioon myös suunnittelemattomien tekijöiden vaikutus oppimistilanteeseen. Opettajien on oltava kaiken aikaa valmistautuneita siihen, että tilanteet saattavatkin lopulta muodostua toisenlaisiksi kuin oli suunniteltu, ja myös oppiminen voi tästä syystä olla lopulta jotakin muuta, kuin mitä tavoiteltiin. (Cooper ym. 2004.) Moniammatillinen suursimulaatio-opetus kuten perinteisempi simulaatio-opetuskin moniammatillisesti toteutettuna on haaste opettajien pedagogisille taidoille ja vaatii hyviä taitoja paitsi oppimiskeskustelun vetämiseen, myös esimerkiksi suuren osallistujamäärän osallistamiseen keskusteluun (ASPiH 2017; Hellström ym. 2015). Tässä vuorovaikutustaitojen lisäksi erilaisten teknisten apuvälineiden käytön hallitseminen on olennaista.

Simulaatio-oppimisessa tavoitteena on usein nimenomaan yhteistyö- ja vuorovaikutustaitojen oppiminen (esim. Liaw ym. 2014), ja siksi on tärkeää, että simulaatioharjoituksen käsikirjoitus virittää huomaamaan sekä toivottuja että ei- toivottuja seikkoja kohtaamisesta. Tämä lähtökohta on toteutunut hyvin suursimulaatioissa. Simulaatio-oppimisessa tavoitteiden tulee ohjata simulaation etenemistä ja oppimiskeskustelun tulee kohdistua tavoitteisiin (Husebo ym. 2013). Toteutuneissa suursimulaatioissa tavoitteiden ja saavutettujen oppimiskokemusten välinen yhteys oli selkeä ja tuli esiin monipuolisesti opiskelijoiden reflektioissa. Tältä osin suursimulaatiota voi pitää onnistuneena simulaatio-oppimisen uutena pedagogisena sovelluksena.

Tutkimusasetelmaamme ja sen tuottamia tuloksia pitää tarkastella myös kriittisesti. Olemme toteuttaneet tämän artikkelin kirjoittamishetkellä vain kaksi suursimulaatiota, joten tuloksemme eivät ole yleistettävissä laajemmin suursimulaatio-oppimisen kokemuksiksi. Osin samasta syystä myös aineistona olleita opiskelijareflektioita oli määrällisesti melko vähän. Analysoidut reflektiot olivat lisäksi ainoastaan kahden oppiaineen, sosiaalityön ja sosiaalipsykologian opiskelijoiden tuottamia, sillä toisten suursimulaatioihin osallistuneiden tieteenalojen opiskelijoille ei ollut esitetty vastaavia tehtävänantoja. Jatkossa olisi kiinnostavaa tutkia useampien eri tieteenalojen edustajien kokemuksia simulaatioista, ja myös vertailla niitä keskenään.

Suursimulaatiot ovat oppimisen näkökulmasta tutkimuksemme mukaan vaikuttavia. $\mathrm{Ne}$ ovat myös kustannustehokkaita verrattuna perinteiseen simulaatio-oppimiseen, joka vaatii pienryhmäopetusta ja siksi vahvaa opettajaresursointia. Suursimulaa- 
tiotkin vaativat aikaa ja paneutumista suunnitteluvaiheessa, mutta kun itse toteutukseen voi kerralla osallistua satoja opiskelijoita, tehty työ on tehokasta opettaja- ja opiskelijamäärän suhdetta arvioitaessa. Suurryhmäsimulaatiot voidaan myös tallentaa jatkokäyttöön, kun esiintyjinä toimivat muut kuin opiskelijat, ja heiltä on saatu asianmukaiset luvat tallenteiden myöhempää käyttöä varten. Kun huomioon otetaan tässä tutkimuksessa saadut tulokset opiskelijoiden kokemuksista suursimulaatioista oppimisen näkökulmasta, olemmekin vahvasti sitä mieltä, että suursimulaatioopetusta on mielekästä jatkaa ja kehittää edelleen. Suursimulaatioissa on myös jatkossa tärkeää käsitellä sellaisia teemoja, jotka koskettavat osallistujia emotionaalisesti, sillä tunteita herättäneiden kokemusten pohdinta tuotti erityisen vahvoja oppimiskokemuksia.

\section{KirjallisuUs}

Association for Simulated Practice in Healthcare (ASPiH) (2017) Simulationbased education in healthcare: Standards framework and guidance. England: AS$\mathrm{PiH}$. http://aspih.org.uk/standardsframework-for-sbe/ Luettu 1.10.2018.

Bambini, Deborah (2016) Writing a simulation scenario. Advanced Critical Care 27 (1), 6-70. https://doi.org/10.4037/ aacnacc2016986

Banks, Sarah \& Williams, Robin (2005) Accounting for ethical difficulties in social welfare work: Issues, problems and dilemmas. British Journal of Social Work 35 (7), 1005-1022. https://doi. org/10.1093/bjsw/bch199

Bayne-Smith, Marcia \& Mizrahi, Terry \& Korazim-Körösy,Yossi, \& Garcia, Martha (2014) Professional identity and participation in interprofessional community collaboration. Issues in Interdisciplinary Studies 32, 103-133.

Blakey, Joan M. (2014) We're all in this together: Moving toward an interdisciplinary model of practice between child protection and substance abuse treatment professionals. Journal of Public Child Welfare 8 (5), 491-513. https://doi.org/ 10.1080/15548732.2014.948583

Bland, Andrew J \& Topping, Annie \& Wood, Barbara (2011) A concept analysis of simulation as learning strategy in the education of undergraduate nursing students. Nurse Education Today 31 (7), 664-670. https://doi.org/10.1016/j. nedt.2010.10.013

Bland, Andrew \& Tobbell, Jane (2016) Towards an understanding of the attributes of simulation that enable learning in undergraduate nurse education: A grounded theory study. Nurse Education Today 44, 8-13. https://doi.org/10.1016/j. nedt.2016.05.011

Bronstein, Laura (2003) A model for interdisciplinary collaboration. Social Work 48 (3), 297-306. https://doi.org/10.1093/ $\mathrm{sw} / 48.3 .297$

Cooper, Helen \& Braye, Suzy \& Geyer, Robert (2004) Complexity and interprofessional education. Learning in Health and Social Care 3 (4), 179-189. https://doi.org/10.1111/j.14736861.2004.00076.x

Costello, Margareth \& Prelack, Kathrina \& Faller, Josephine \& Huddleston, Jim \& Adly, Sylvana \& Doolin, Jade (2018) Student experiences of interprofessional simulation: Findings from a qualitative study. Journal of Interprofessional Care 32 (1), 95-97. https://doi.org/10.1080/ 13561820.2017.1356810

Dreifuerst, Kristina Thomas (2012) Using debriefing for meaningful learning to foster development of clinical reasoning in simulation. Journal of Nursing Education 51, 326-333. https://doi. org/10.3928/01484834-20120409-02

Dufrene, Claudine \& Young, Anne (2014) Successful debriefing - Best methods to achieve positive learning outcomes: A literature review. Nurse Education Today 34 (3), 372-376. https://doi. org/10.1016/j.nedt.2013.06.026

Eteläpelto, Anneli \& Collin, Kaija \& Silvennoinen, Minna (2013) Simulaatiokoulutuksen pedagogiikkaa. Teoksessa Per Rosenberg, Minna Silvennoinen, 
Minna-Maria Mattila, Jorma Jokela \& Iiri Ranta (toim.) Simulaatio-oppiminen terveydenhuollossa. Helsinki: Fioca, 14-39.

Failla, KimReina, \& Macauley, Karen (2014) Interprofessional simulation: concept analysis. Clinical Simulation in Nursing 10 (11), 574-580. https://doi. org/10.1016/j.ecns.2014.07.006

Foronda, Cynthia \& MacWilliams, Brent \& McArthur, Erin (2016) Interprofessional communication in healthcare: an integrative review. Nurse Education in Practice 19, 36-40. https://doi.org/10.1016/j. nepr.2016.04.005

Hellström, Martti \& Johnson, Peter \& Leppilampi, Asko \& Sahlberg, Peter (2015) Yhdessä oppiminen. Yhteistoiminnallisuuden käytäntö ja periaatteet. Helsinki: Into Kustannus.

Herrmann, Gudrun \& Woermann, Ulrich \& Schlegel, Claudia (2015) Interprofessional education in anatomy: learning together in medical and nursing training. Anatomical Sciences Education 8, 324330. https://doi.org/10.1002/ase.1506

Hibbert, Paul \& Siedlok, Franck, \& Beech, Nick (2016) The role of interpretation in learning practices in the context of collaboration. Academy of Management Learning and Education 15 (1), 26-44. https://doi.org/10.5465/ amle.2014.0004

Hooper, Barbara \& Shaw, Luanne \& Zamzam, Rebekh (2015) Implementing high-fidelity simulations with large groups of nursing students. Nurse Educator 40 (2), 87-90. https://doi. org/10.1097/NNE.0000000000000101

Hovland, Cynthia \& Whitford, Maureen \& Niederriter, Joan (2018) Interprofessional education: insights from a cohort of nursing students. Journal for Nurses in Professional Development 34 (4), 219-225. https://doi.org/10.1097/ NND.0000000000000466

Husebo, Sissel \& Dieckmann, Peter \& Rystedt, Hans \& Soreide, Eldar \& Friberg, Febe (2013) The relationship between facilitators' questions and the level of reflection in postsimulation debriefing. Simulation in Healthcare 8 (3), 135-142. https://doi.org/10.1097/ SIH.0b013e31827cbb5c
Isoherranen, Kaarina (2012) Uhka vai mahdollisuus - moniammatillista yhteistyötä kehittämässä. Väitöskirja. Helsinki: Helsingin yliopisto.

Kekoni, Taru \& Mönkkönen, Kaarina \& Hujala, Anneli \& Laulainen, Sanna \& Hirvonen, Jukka (2019) Moniammatillisuus käsitteinä ja käytänteinä. Teoksessa Kaarina Mönkkönen, Taru Kekoni \& Aini Pehkonen (toim.) Moniammatillinen yhteistyö. Vaikuttava vuorovaikutus sosiaali- ja terveysalalla. Helsinki: Gaudeamus, 15-46.

Khalili, Hossein \& Orchard, Carole \& Spence Lashinger, Heather K \& Farah, Randa (2013) An interprofessional socialization framework for developing an interprofessional identity among health professions students. Journal of Interprofessional Care 27 (6), 448-53. https:// doi.org/10.3109/13561820.2013.8040 42

Kolb, David (1984) Experiential Learning: Experience as the Source of Learning and Development. Englewood Cliffs, NJ: Prentice-Hall, Inc.

Kuehn, Mary Beth \& Huehn, Susan \& Smalling, Susan (2017) Improving collaboration among social work and nursing students through interprofessional simulation. Creative Nursing 23 (3), 179183. https://doi.org/10.1891/10784535.23.3.179

Labrague, Leodoro \& McEnroe-Petitte, Denise, Fronda \& Dennis, \& Obeidat, Arwa (2018) Interprofessional simulation in undergraduate nursing program: an integrative review. Nurse Education Today 67, 46-55. https://doi.org/10.1016/j. nedt.2018.05.001

Lavoie, Patrick \& Pepin, Jacinthe \& Cossette, Sylvie (2015) Development of a post-simulation debriefing intervention to prepare nurses and nursing students to care for deteriorating patients. Nurse Education in Practice 15 (3), 181-191. https://doi.org/10.1016/j. nepr.2015.01.006

Lestari, Endang \& Stalmeijer, Renne \& Widyandana, Doni \& Scherpbier, Albert (2016) Understanding students' readiness for interprofessional learning in an Asian context: a mixed-methods study. BMC Medical Education 16 (1), 179. 
https://doi.org/10.1186/s12909-0160704-3

Liaw, Sok. \& Zhou, Wentao \& Lau, Tang \& Siau, Chiang \& Chan, Wai (2014) An interprofessional communication training using simulation to enhance safe care for a deteriorating patient. Nurse Education Today 34 (2), 259-264. https://doi. org/10.1016/j.nedt.2013.02.019

Mikkeli, Heikki \& Pakkasvirta, Jussi (2007) Tieteiden välissä. Johdatus monitieteisyyteen, tieteidenvälisyyteen ja poikkitieteisyyteen. Helsinki: WSOY Oppimateriaalit. https://helda.helsinki. fi/handle/10138/214833 Luettu 3.11. 2021.

Murdoch, Natalie \& Epp, Sheila \& Vinek, Jeanette (2017) Teaching and learning activities to educate nursing students for interprofessional collaboration: A scoping review. Journal of Interprofessional Care 31 (6), 744-753. https://doi.org/1 0.1080/13561820.2017.1356807

Mönkkönen, Kaarina \& Kekoni, Taru \& Pehkonen, Aini (toim.) (2019) Moniammatillinen yhteistyö.Vaikuttava vuorovaikutus sosiaali- ja terveysalalla. Helsinki: Gaudeamus.

Mönkkönen, Kaarina \& Kekoni, Taru (2020) Monitoimijaisuus työntekijän voimavarana ja haasteena. Teoksessa Anneli Hujala \& Helena Taskinen (toim.) Uudistuva sosiaali- ja terveysala. Tampere:Tampere University Press, 216-240.

Mönkkönen, Kaarina \& Sílen-Lipponen, Marja \& Kekoni, Taru \& Saaranen, Terhi (2021) Interprofessional understanding of ethical dilemmas: Learning experiences of simulation learning in social welfare and health care education. The Journal of Social Work Values and Ethics 18 (2), 16-28. https://jswve.org/ download/2021-2/7-Interprofessional-Understanding-of-Ethical-Dilemmas-JSWVE-18-2-2021.pdf Luettu 3.11.2021.

OKM (2019) Tutkintoon johtavan koulutuksen kehittäminen tukemaan sosiaalija terveyspalvelujen uudistamista. Opetus- ja kulttuuriministeriön julkaisuja 2019:24. Helsinki: Opetus- ja kulttuuriministeriö.

Pinto, Casey \& Possanza, Anthony \& Karpa, Kelly (2018) Examining student perceptions of an inter-institutional interprofessional stroke simulation activity. Journal of Interprofessional Care 32 (3), 391-394. https://doi.org/10.1080/1356 1820.2017.1405921

Reime, Marit Hegg \& Johnsgaard, Tone \& Kvam, Fred Ivan \& Aarflot, Morten \& Engeberg, Janecke Merethe \& Breivik, Marit \& Brattebø, Guttorm (2017) Learning by viewing versus learning by doing: A comparative study of observer and participant experiences during an interprofessional simulation training. Journal of Interprofessional Care 31 (1), 51-58. https://doi.org/10.1080/135 61820.2016 .1233390

Roberts, Fiona E. \& Goodhand, Kate (2018) Scottish healthcare student's perceptions of an interprofessional ward simulation: An exploratory, descriptive study. Nursing \& Health Sciences 20 (1), 107-115. https://doi.org/10.1111/ nhs. 12393

Rode, Jennifer L. \& Callihan, Michael \& Barnes, Brenda L. (2016) Assessing the value of large-group simulation in the classroom. Clinical Simulation in Nursing 12 (7), 251-259. https://doi. org/10.1016/j.ecns.2016.02.012

Saaranen, Terhi \& Sílen-Lipponen, Marja \& Palkolahti, Maria \& Mönkkönen, Kaarina \& Tiihonen, Miia \& Sormunen, Marjorita 2020. Interprofessional learning in social and healthcare - learning experiences from large-group simulation in Finland. Nursing Open 7 (6), 1978-1987. https://doi.org/10.1002/ nop2.589

van Schaik, Sandrijn \& Plant, Jennifer \& O'Brien, Bridget (2015) Challenges of interprofessional team training: A qualitative analysis of residents' perceptions. Education for Health: Change in Learning and Practice 28 (1), 52-57. https:// doi.org/10.4103/1357-6283.161883

Schreier, Margit (2012) Qualitative content analysis in practice. Los Angeles, London, New Delhi, Singapore, Washington DC: Sage.

Schramm, Garret \& Narayanan, Prasanna \& Chutka, Darryl S. \& Nicholson, Wayne (2017)_Implementation of an interprofessional clinical pharmacology selective learning experience for pharmacy resi- 
dents and medical students. American Journal of Health-System Pharmacy 74 (6), 397-401. https://doi.org/10.2146/ ajhp160112

Shrader, Sarah \& Kern, Donna \& Zoller, James, \& Blue, Amy (2013) Interprofessional teamwork skills as predictors of clinical outcomes in a simulated healthcare setting. Journal of Allied Health, 42 (1), 1-6.

Smith, Leslie \& Keiser, Megan \& Turkelson, Garman \& Yorke, Amy \& Sachs, Benjamin \& Berg, Karen (2018) Simulated interprofessional education discharge planning meeting to improve skills necessary for effective interprofessional practice. Professional Case Management 23 (2), 75-83. https://doi.org/10.1097/ NCM.0000000000000250

Stanley, Karen \& Stanley, David (2019) The HEIPS framework: Scaffolding interprofessional education starts with health professional educators. Nurse Education in Practice 34, 63-71. https://doi. org/10.1016/j.nepr.2018.11.004

Stegmann, Karsten \& Pilz, Florian \& Siebeck, Matthias \& Fischer, Frank (2012) Vicarious learning during simulations: Is it more effective than hands-on training? Medical Education 46, 1001-1008. https://doi.org/10.1111/j.13652923.2012.04344.x

Tervaskanto-Mäentausta, Tiina (2018) Interprofessional Education during Undergraduate Medical and Health Care Studies. Väitöskirja. Oulu: Oulun yliopisto.

Tuomi, Jouni \& Sarajärvi, Anneli (2018) Laadullinen tutkimus ja sisällönanalyysi. Helsinki: Kustannusosakeyhtiö Tammi.

Tynjälä, Päivi (2007) Integratiivinen pedagogiikka osaamisen kehittämisessä. Teoksessa Hannu Kotila, Arto Mutanen, \& Matti Vesa Volanen (toim.) Taidon tieto. Helsinki: Edita, 11-36.
Tynjälä, Päivi \& Virtanen, Anne \& Klemola, Ulla \& Kostiainen, Emma \& Rasku-Puttonen, Helena (2016) Developing social competence and other generic skills in teacher education: applying the model of integrative pedagogy. European Journal of Teacher Education 39 (3), 368-387. http://dx.doi.org/10.1080/02619768.2 016.1171314

Wang, Jin Na \& Petrini Marcia (2017) Chinese health students' perceptions of simulation-based interprofessional learning. Clinical Simulation in Nursing 13 (4), 168-175. https://doi.org/10.1016/j. ecns.2016.12.002

Weller, Jennifer \& Nestel, Debra \& Marshall, Stuart \& Brooks, Peter \& Conn, Jennifer (2012) Simulation on clinical teaching and learning. Medical Journal of Australia 196 (9), 594. https://doi. org $/ 10.5694 / \mathrm{mja} 10.11474$

Zamjahn, John B. \& Beyer, Ellen O. \& Alig, Kelly L. \& Mercante, Donald E. \& Carter, Katherine L. \& Gunaldo, Tina P. (2018) Increasing awareness of the roles, knowledge, and skills of respiratory therapists through an interprofessional education experience. Respiratory Care 63 (5), 510-518. https://doi.org/10.4187/respcare.05869

Äikäs, Aino \& Mönkkönen, Kaarina \& Issakainen, Mervi \& Kekoni, Taru \& Kasanen, Kati \& Karkkola, Petri (2020) Moniammatillinen opiskelu verkossa yliopisto-opiskelijoiden kokemana. Aikuiskasvatus 40 (2), 112-126. https:// doi.org/10.33336/aik.95451 